\title{
CHINA'S INFLUENCE IN AFRICA: CURRENT ROLES AND FUTURE PROSPECTS IN RESOURCE EXTRACTION
}

\author{
Liu Haifang*
}

\begin{abstract}
In the second half of 2014, some African countries felt the heavy strike of falling prices of mineral resources on the world market. The international media raised vocalex positions on the negative impact that China's slow down might bring to the African economy. One headline read: "Chinese investment in Africa has fallen 40 per cent this year - but it's not all bad news". ${ }^{1}$ More recently, the exasperation intensified to "China's slowdown blights African economies", ${ }^{2}$ and managed to shadow the China-African Summit held in December 2015 in Johannesburg. Similarly, on the recent Africa Mining Indaba, the annual biggest African event for the mining sector, the renewed concern was stated as "Gloom hangs over African mining as China growth slows". ${ }^{3}$ There is no doubt that China's presence has had positive effects on Africa's growth over the past decade. Nonetheless, only a narrow perspective would view Africa's weak performance solely through the Chinese prism. This article addresses the afore-mentioned concerns regarding the impacts that China has in Africa. A historical approach is applied to reconstruct
\end{abstract}

* PhD (Peking), Associate Professor, Deputy Director and Secretary General of the Centre for African Studies, School of International Studies, Peking University, China. Email: liuhaifang@pku.edu.cn

1 Quartz Africa Weekly Africa, "Chinese investment in Africa has fallen $40 \%$ this year-but it's not all bad news", 18 November 2015, available online at <http:/ /finance.yahoo.com/news/chinese-investment-africa-fallen-40-060057915. html;_ylt =AwrXnCdOG09WvjIAxUuamolQ;_ylu=X3oDMTByb2lvbXVu BGNvbG8DZ3ExBHBvcwMxBHZ0aWQDBHNlYwNzcg > available online 10 February 2016.

2 The Age (Australia), "China's slowdown blights African economies", 3 February 2016 <http://www.theage.com.au/world/chinas-slowdown-blights-africaneconomies-20160203-gmkcte.html\#ixzz409rM93so > available online 10 February 2016.

3 AFP, "Gloom hangs over African mining as China growth slows" < http:// finance.yahoo.com/news/gloom-hangs-over-african-mining-china-growthslows104650035.html;_ylt=AwrXoCHD7b9W72EABv.TmYlQ; ylu=X3oDMTEyZ GJhZXByBGNvbG8DZ3ExBHBvcwMIntrodu0BHZ0aWQDVklEQzFfMQRz ZWMDc2M > available online 10 February 2016. 
the economic cooperation since the mid-1990s. This reconstruction emphasizes the sustaining forces of cooperation. Literally, this article goes beyond the resource traction sector, to understand the basis of China-African cooperation, and the position mineral resource has taken in the bilateral cooperation. With a representative country case study, the current dilemma is shown from the structure of bilateral cooperation. Suggestions follow on how to address these challenges.

Keywords: China, Africa, mining, resource, investment, development.

DOI: https://dx.doi.org/10.4314/jsdlp.v8i1.3

\section{INTRODUCTION}

Africa has been relevant in China's global strategy beyond the resource sector. As the resource hunger hypothesis has been the popular assumption behind the motivation of China's interest in the African continent, ${ }^{4}$ it is not surprising to see this need for resource regarded as decisive, for positive or negative implications on the African continent. Consequently, China's influence has only been watched through the mining sector.

Three subsequent graphs (Figures 1-3) show that Africa's economic partners are diversified, and China is yet to become the most important player, in terms of African crude oil, or metal as well as non-metal mineral resources export. For example, in 2009 when Europe and United States were suffering from a severe financial crisis, these remained the most important importers of African mineral resource.

\section{CHINA'S INCREASING RESOURCE DEMAND}

An examination of the 45 kinds of mineral reserves held by the top ten countries in the world shows that China is third in the world rank for a total value of mineral reserves, following US and

4 Such as China accused ofs upporting African dictatorships, hindering economic development, and exacerbating existing conflicts and human rights abuses in troubled countries through its business with these countries", see Peter Brookes and Ji H. Shin, "China's Influence in Africa: Implications for the United States," Backgrounder, No. 1916, 22 February 2006, p. 11. 


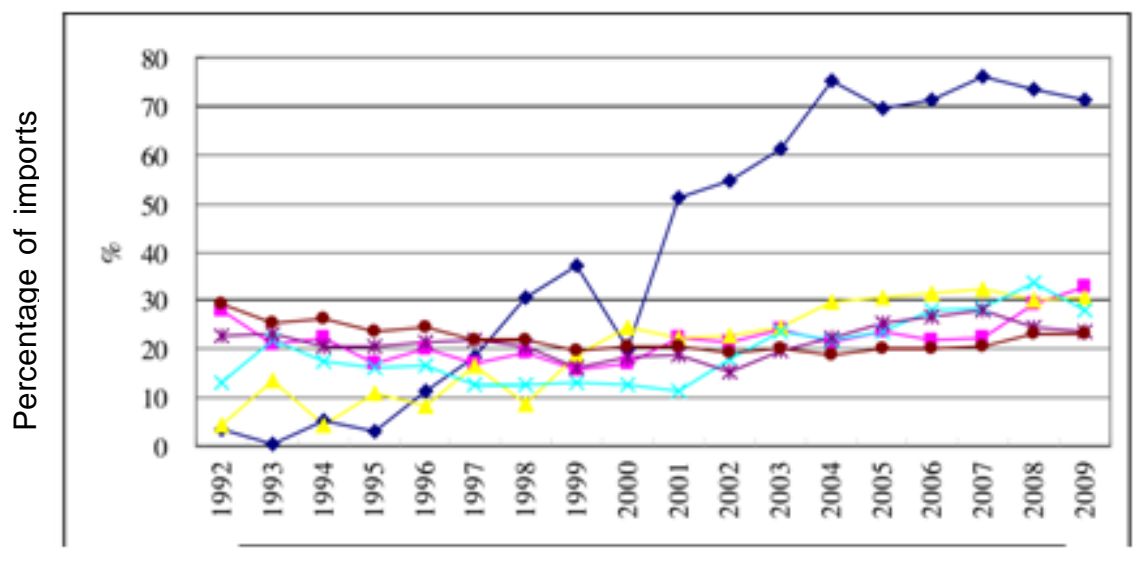

—Brazil -_France _ China -Canada _-US —-EU

Figure 1. Importers of Crude Oil from Africa, 1992-2009

Source: UN Comtrade, 2010.

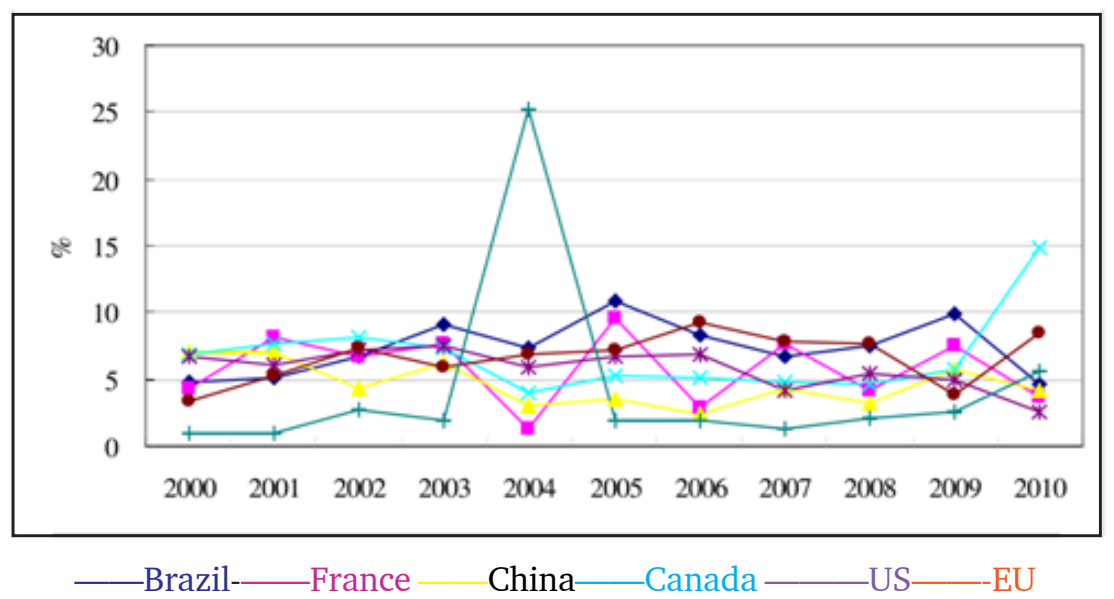

Figure 2. Importers of Non-Metal Mineral Resources from Africa, 2000-2010 Sources: UN Comtrade, 2011. 


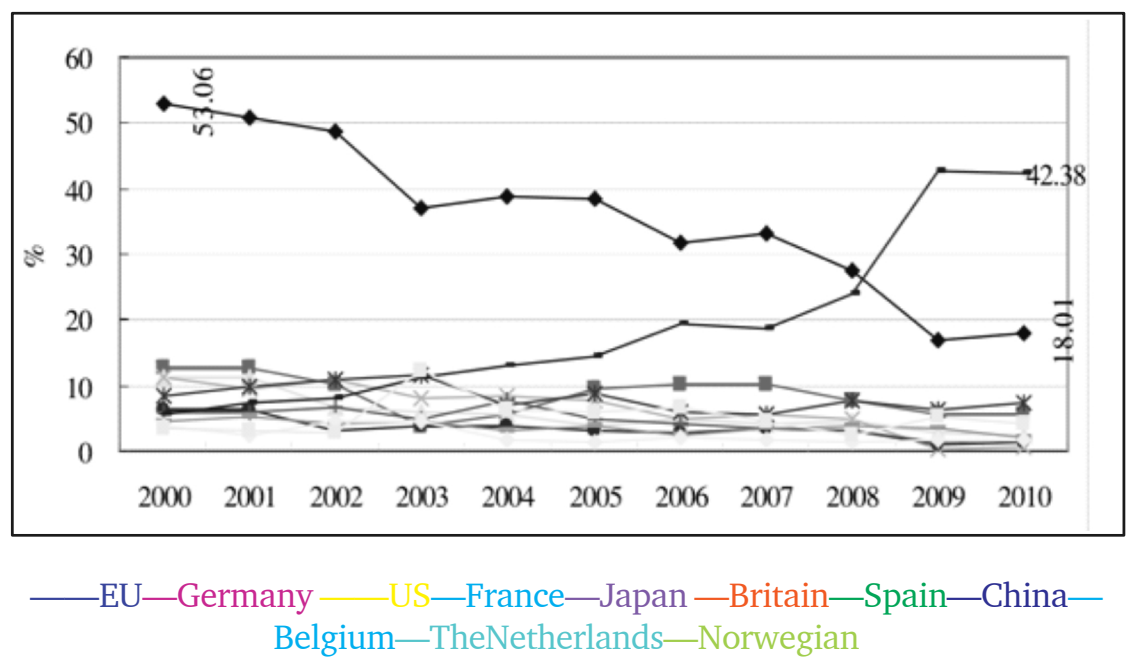

Figure 3. Countries Importing Metal Mineral Resource from Africa, 20002009

Sources: UN Comtrade, 2011.

Russia. ${ }^{5}$ The image of "China's vast territory and abundant resources" had been so familiar to Chinese nationals before the new century. Notably, the average per capita of China's mineral reserves is as low as 58 per cent of that of the world. ${ }^{6}$ China's economic transformation since the 1980s has created a rigid need for mineral resources, as the term "vast territory and abundant resources" gradually disappeared from the textbooks by the end of the 20th century. Major minerals like petroleum, natural gas, copper, iron, coal and bauxite and so on started being sourced from abroad. ${ }^{7}$ The increasing trend in resource imports as at 2014 vis-á-vis 2009 by China can be seen in the following table.

5 China Mining Association (CMA), "The Position of China's Mineral Resource in the World" < http://en.chinamining.com.cn/Facts/2006-09-19/1158646844 d1231.html> accessed May 2nd, 2016.

6 Control Engineering and Information Systems: Proceedings of the 2014 International Conference on Control Engineering and Information Systems (ICCEIS 2014, Yueyang, Hunan, China, 20-22 June 2014). Zhijing Liu.

7 CCTV Documentary: China's Memorandum, “China's Vast Territory and Abundant Resources, Not Any More”, Zhong Guo JiTi Jingji (China's Collective Economy), Iss. 10, 2010, pp. 18-19. 
Table 1. World Production of Selected Minerals Resource and China's Consumption

\begin{tabular}{|c|c|c|c|c|}
\hline Items & $\begin{array}{l}\text { World's } \\
\text { production } \\
(2008)\end{array}$ & $\begin{array}{l}\text { China's } \\
\text { production } \\
(2009)\end{array}$ & $\begin{array}{l}\text { China's } \\
\text { import } \\
(2009)\end{array}$ & $\begin{array}{l}\text { China's } \\
\text { import in } \\
2014\end{array}$ \\
\hline Petroleum & $\begin{array}{l}185.504 \text { billion } \\
\text { tons }\end{array}$ & $\begin{array}{l}28.929 \text { billion } \\
\text { tons }\end{array}$ & $\begin{array}{l}0.2189 \text { billion } \\
\text { tons }\end{array}$ & $\begin{array}{l}0.31 \text { billion } \\
\text { tons }\end{array}$ \\
\hline Gas & $1.77 * 10^{14} \mathrm{~m}^{3}$ & $\begin{array}{l}7840 \text { billion } \\
\mathrm{m}^{3}\end{array}$ & $\begin{array}{l}77.4 \text { billion } \\
\mathrm{m}^{3}\end{array}$ & $\begin{array}{l}269.92 \text { billion } \\
\mathrm{m}^{3}\end{array}$ \\
\hline Copper & $\begin{array}{l}0.55 \text { billion } \\
\text { tons }\end{array}$ & $\begin{array}{l}0.0716 \text { billion } \\
\text { tons }\end{array}$ & $\begin{array}{l}4.29 \text { million } \\
\text { tons }\end{array}$ & $\begin{array}{l}4.825 \text { million } \\
\text { tons }\end{array}$ \\
\hline Iron ore & $\begin{array}{l}150 \text { billion } \\
\text { tons }\end{array}$ & $\begin{array}{l}62.4 \text { billion } \\
\text { tons }\end{array}$ & $\begin{array}{l}0.628 \text { billion } \\
\text { tons }\end{array}$ & $\begin{array}{l}0.93 \text { billion } \\
\text { tons }\end{array}$ \\
\hline Coal & - & - & $\begin{array}{l}0.12583 \\
\text { billion tons }\end{array}$ & $\begin{array}{l}0.29 \text { billion } \\
\text { tons }\end{array}$ \\
\hline Bauxite & 27 billion tons & $\begin{array}{l}0.539 \text { billion } \\
\text { tons }\end{array}$ & $\begin{array}{l}2.579 \text { million } \\
\text { tons }\end{array}$ & $\begin{array}{l}3.628 \text { million } \\
\text { tons }\end{array}$ \\
\hline
\end{tabular}

Sources: Chinese General Administration of Customs, 2015.

For instance, with oil as an example, using internal reserves, China became oil sufficient in 1963 and its oil export peaked in 1985. Observably, a sea change took place very rapidly as reforms such as openness became the policy drive; the whole economy was transformed and the industrialization generated heavy demand for oil, so fast so that since 1993 China has become a net oil importer (Figure 4).

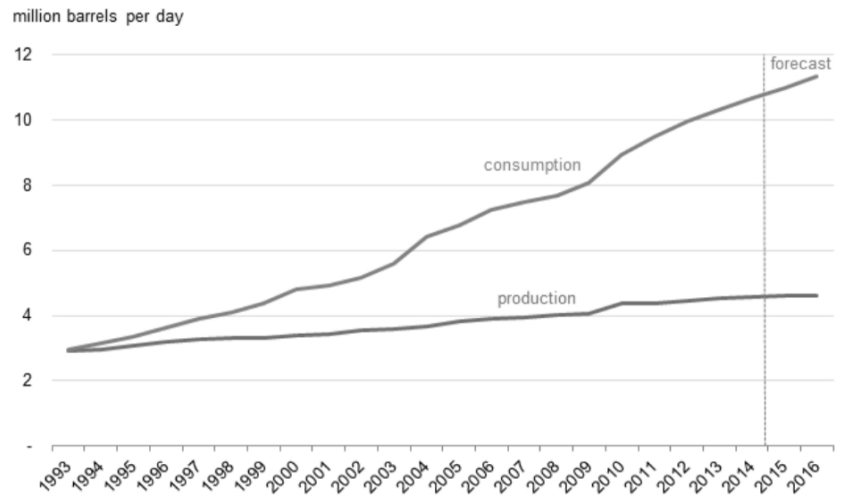

Figure 4. Daily Oil Production and Consumption in China, 1993-2016 8 Source: EIA, "International Energy Statistics and Short-term Energy Outlook, 2015.

8 EIA, "International Energy Statistics and Short-term Energy Outlook", May 2015, refer to <http://www.eia.gov/countries/cab.cfm?fips $=\mathrm{CH}>$ accessed 2 May 2015. 
At the initial stage, due to limited capacity to import resources through trade, Chinese companies started to think of foreign investment. Only in 1987, for the first time, did China Metallurgical Import and Export Corporate become approved by the State Council to jointly invest in Australian iron mining with a local partner. Thereafter, other investment in mining projects gradually followed, including oil exploitation by Chinese oil companies. These continued in the middle 1990s in several countries, such as Peru, Venezuela, Canada, Thailand, Sudan, and Kazakhstan. ${ }^{9}$

In 2001, the Chinese Academy of Sciences published a report entitled, "Two Resources, Two Markets: A Study on China's Resources Safety Guarantee System", suggesting a go-global strategy to use both domestic and international resources as well as markets. ${ }^{10}$ Around 2003, this go-global strategy was formally incorporated into the then Chinese Premier Wen Jiabao's comprehensive economic development strategy. Since then, in order to establish a long-term resource security, Chinese companies were encouraged to increasingly invest in the mining sector abroad, from an energy resource to iron ore, copper, tin, zinc, nickel, and uranium. For the sake of diversifying energy resource, Chinese companies are also encouraged to incorporate in nontraditional energy sources like nuclear, solar and other renewable areas as well as in petroleum. However, as a newcomer, China's investment in the extractive resource sector is only growing gradually due to many practical reasons, and trade in mineral resources for a long time has been playing, and still plays, a major role in China's engagement with the global economy. According to Communiqué on Land and Resources of China 2014, the total volume of import and export of mineral resources was US\$1.09 trillion in 2014, accounting for 25.3 per cent of China's total foreign trade in 2014. ${ }^{11}$

As supplying sources of most needed minerals has become a very important agenda, while the security risks in the world are becoming

9 Gu Xueming, "China's Mineral Resource Strategy in Africa: A Study from Perspective of Trade and Investment". A Dissertation Submitted to China University of Geosciences for Doctoral Degree, 2011, pp. 33-34.

10 Centre for Contemporary China's Study, “Two Resources, Two Markets: A Study on China's Resources Safety Gurantee System. National Land and Resources Information, ISS. 2, 2001, pp. 28-35.

11 Ministry of Land and Resources, PRC, Communique on Land and Resources of China 2014 available <http://www.mlr.gov.cn/zwgk/zytz/201504/ P020150422317433127066.pdf> accessed 2 May 2015. 
increasingly challenging, the Chinese government has realized the relevance of diplomatic instruments to enhance its partnership with more parts of the world to diversify the resource supply. We use the example of oil to explain this trend.

Table 2. Chinese Oil Imports by Regions with Relative Change $(\uparrow / \downarrow)$, Selected Years $^{12}(\%)$

\begin{tabular}{lccccccccc}
\hline & $\begin{array}{c}1990 \\
(\%)\end{array}$ & $2000(\%)$ & $2004(\%)$ & $2010(\%)$ & 2014 (\%) \\
\hline Middle & 39.4 & 53.5 & $\uparrow$ & 45.4 & $?$ & 47.1 & $\uparrow$ & 52.2 & $\uparrow$ \\
East & & & & & & & & & \\
Africa & 0 & 23 & $\uparrow \uparrow$ & 28.7 & $\uparrow$ & 29.3 & $\uparrow$ & 22.0 & $\downarrow$ \\
Asia- & 60.6 & 15.1 & $\downarrow \downarrow$ & 11.5 & $\downarrow$ & 3.7 & $\downarrow$ & 2.1 & $\downarrow$ \\
Pacific & & & & & & & & & \\
Others & 0 & 7.2 & $\uparrow$ & 14.3 & $\uparrow$ & 19.9 & $\uparrow$ & 23.7 & $\uparrow$ \\
\hline
\end{tabular}

Source: EIA, Energy Information Administration, 2015.

Beginning from 1999, over 40 per cent of Chinese crude oil supply has come mainly from the Middle East, with the total volume increasing till 2005. However, the Iraqi war in the previous decade and the Libyan crisis since 2011 have both greatly influenced Chinese companies' petroleum trade deals with the Middle East. Accordingly, Africa has since become a relatively stable oil supplier to the Chinese market (see Table 3). Thus, oil from a single country like Angola, which replaced Saudi Arab as the biggest supplier to China, accounted for 14 per cent of the total importation in 2013. ${ }^{13}$

12 Table made by author according to US Energy Information Administration, China Report available: <http://www.eia.gov/countries/cab.cfm?fips $=\mathrm{CH}>$ accessed 30 April 2015 and latest statistics from China Customs <http:// www.customs.gov.cn>

13 The Statistics Portal, "Breakdown of China's Crude Oil Imports in 2013, By Source Country" < http://www.statista.com/statistics/221765/chinese-oilimports-by-country/> accessed 2 May 2015. 
Table 3. Chinese Crude Import by Country (thousand b/d) ${ }^{14}$

\begin{tabular}{lrrrrrrrr}
\hline & 2007 & 2008 & 2009 & 2010 & 2011 & 2012 & 2013 & 2014 \\
\hline Saudi Arabia & 528 & 727 & 841 & 895 & 1,008, & 1,078 & 1,081 & 989 \\
Angola & 501 & 598 & 645 & 790 & 625 & 803 & 802 & 806 \\
Russia & 291 & 233 & 307 & 306 & 371 & 487 & 490 & 644 \\
Iraq & 28 & 37 & 144 & 225 & 276 & 314 & 472 & 573 \\
Iran & 412 & 426 & 464 & 428 & 557 & 440 & 430 & 546 \\
Other & 1,454 & 1,556 & 1,659 & 2,166 & 2,228 & 2,300 & 2,383 & 2,534 \\
\hline OPEC & 1,817 & 2,255 & 2,618 & 3,029 & 3,165 & 3,578 & 3,617 & 3,717 \\
non-OPEC & 1,398 & 1,323 & 1,443 & 1,750 & 1,900 & 1,844 & 2,041 & 2,376 \\
\hline Norh America & 9 & 2 & 9 & 23 & 46 & 36 & 30 & 18 \\
South America & 206 & 254 & 238 & 393 & 430 & 533 & 534 & 635 \\
Africa & 1,003 & 1,068 & 1,224 & 1,404 & 1,201 & 1,284 & 1,285 & 1,342 \\
Asia Pacific & 119 & 112 & 201 & 179 & 179 & 160 & 132 & 125 \\
FSU & 412 & 349 & 432 & 510 & 598 & 704 & 734 & 765 \\
Middle East & 1,459 & 1,792 & 1,955 & 2,261 & 2,608 & 2,700 & 2,939 & 3,178 \\
Europe & 6 & - & 3 & 7 & 3 & 5 & 4 & 30 \\
\hline Total & 3,216 & 3,578 & 4,061 & 4,800 & 5,085 & 5,422 & 5,658 & 6,092 \\
\hline
\end{tabular}

Source: Chinese General Administration of Customs, 2015.

The criterion to identify the strategic partners for China's mining going-global strategy emphasized two sides: one is that those resources that China is in need of and lack; and the second side is the potential of the resources in those countries. Neighbouring countries were selected as the braces, African countries as main objects and Latin America as considered region. ${ }^{15}$

\section{CHINA'S NEEDS FROM AFRICA: RESOURCES AND BEYOND}

However important, mineral resource stands as only one of China's interests among many from Africa. Indeed, according to UN COMTRADE, natural resources are a major part of the export from Africa to China - more than half of the total value, 59.6 per cent in

14 Table from China Customs, "Chinese Crude Import by Country" < http:// www.customs.gov.cn> accessed 2 May 2015.

15 Gu Xueming, China's Mineral Resource Strategy in Africa: A Study from Perspective of Trade and Investment, p. 35. 
2013, for example. ${ }^{16}$ Notably, China's overseas investments in Africa exceeded US\$107 billion in 2013, and accumulated outbound direct investment stock reached over US $\$ 660$ billion. Nonetheless as indicated in Figure 5, mining extraction is only one focus. The underlying assumption behind the conventional image of a single-minded hunt for the resource is the myth of a monolithic China; de facto China's interests in Africa have been rather diversified, and the actors that have enhanced the bilateral cooperation are also very multitudinous. This explains why, in terms of recipient countries of China's investment, mainly there are the Democratic Republic of Congo, Gabon, Guinea, Zambia, South Africa, Tanzania, Mozambique, Kenya, Ethiopia, and Zimbabwe. Notably, Chinese business exists in almost every African country, including Sao Tome \& Principe, Burkina Faso, Swaziland, which have not established any formal diplomatic relations.

Over the past decade and a half, trade between China and Africa has increased significantly, hitting a record high of US $\$ 200$ billion by the end of 2013, with over five per cent increase in $2014 .{ }^{17}$ The Chinese government did give the first incentives for companies that were engaged in foreign trade, such as tax exemption. As mentioned, even after many years of operation in Africa, these Chinese companies still carry their foreign trade corporation identities. Successful going-global companies, such as Huawei and Zhongxing Telecommunications Equipment (ZTE), were able to enjoy rapid absorption into the African market and from there to the wider world.

16 Statistics of China Customs, refer to Liang Ming, "Foreign Trade of Africa" <http://blog.sina.com.cn/s/blog_58acb4140101itpt.html> accessed 2 May 2015.

17 MOFCOM, "General Survey of China-African Economic Cooperation in 2014" <http://www.cn156.com/article-43376-1.html> accessed 2 May, 2015. 


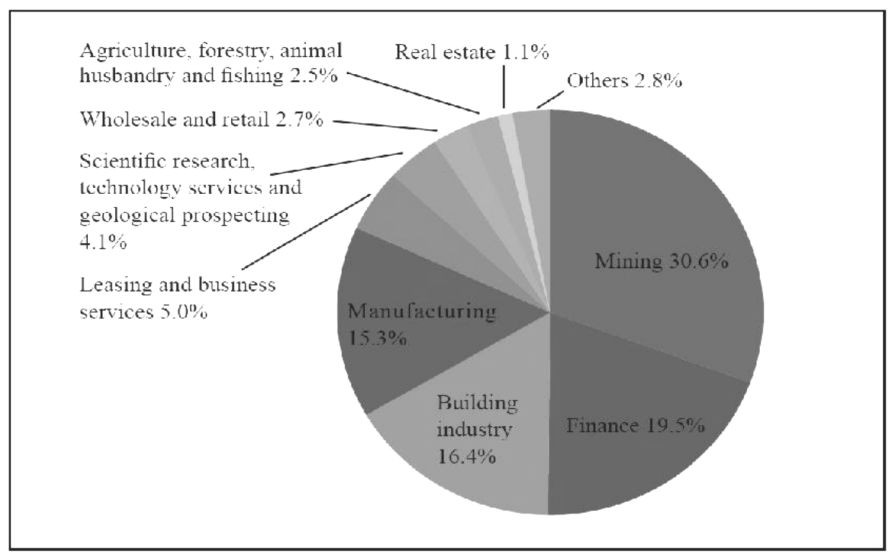

Figure 5. Distribution of China's FDI in Africa, Stock by the End of $2011^{18}$

Source: The Information Office of the State Council, 2013.

As the Chinese domestic construction market became saturated in the 1990s, the Chinese contract service companies, together with trading companies, made up the very first batch of those moving to Africa. After quickly getting their first barrels of the black gold, these companies have diversified their business interests by investing in manufacturing, services, real estate, etc. ${ }^{19}$ This is why, besides a lot of small traders, construction companies are the most visible Chinese business presence on the ground even till today. Small traders and the Chinese coming with state aid projects from the mainland have made up the so-called "new overseas Chinese in Africa", different from the older Chinese migrants mainly from Taiwan, Hong Kong and other Southern Asian countries. ${ }^{20}$ The majority of Chinese companies in Africa so far are still involved in construction, especially in post-conflict

18 The Information Office of the State Council, white paper on "China-Africa Economic and Trade Cooperation", 29 August $2013<$ http://news. xinhuanet.com/english/china/2013-08/29/c_132673093_4.htm > accessed 2 May, 2015.

19 Liu Haifang, "Chinese Companies in Africa: Status quo and trend", 50 years' of China-African Cooperation (eds. by Liu Hongwu \& Yang Jiemian), Yunnan University Publishing House, 2009.

20 Yoon Park, "Chinese Migration in Africa", SAIIA Occasional Paper No. 24, January 2009; Liu Haifang, "Mapping the New Migrants between China and Africa", chapter in book China's Internal and International Migrants (eds. by Li Peilin and Laurence Roulleau-Berger), Rutledge, 2012, pp. 234-244. 
countries like Angola. ${ }^{21}$ Angola only heralded its peace in 2002; hence physical development became a primary goal in its national agenda. Therefore, as reconstruction commenced on the public and private infrastructure, this generated huge opportunities as well as attractions for the migrating Chinese to plunge into the sector. ${ }^{22}$

Indeed, apart from Africa being a strategic resource supplier and because of its friendly environment, the continent was specifically chosen as a pilot field for those Chinese companies going global. Accordingly, specific policies, as well as incentives, were launched to help more Chinese companies to come to Africa to initiate their internationalization project. In 2006, during the China-African Summit meeting, the incumbent Chinese president, $\mathrm{Hu}$ Jintao, facilitated the Chinese companies' settlement in Africa by announcing a new policy instrument, namely China-African Development Fund (CADF).

The CAD Fundhas four main target areas, namely, agriculture and manufactures that could help African countries become self-sufficient, infrastructure and basic industries (such as power, energy production, transportation and urban running water system), mineral resources, and industrial parks opened by Chinese companies. Up till 2014, CAD Fund has investedUS $\$ 3$ billion in over 27 countries, and quite a number of projects (including some mining projects) have been operating smoothly. The very successful cement factory and tannery factory in Ethiopia is an example of these. ${ }^{23}$

Additional incentives like the six special economic zones (SEZs) that have been operating in five African countries, involved in various activities in these economic zones, including mineral processing (instead of exporting the crude material back to China, for example, the ZambiaChina Economic and Trade Cooperation Zone includes copper processing facilities). Also, a large number of Chinese big and small companies have been involved in logistics, services, industries, manufactures, medicals, hotel, trade, and so on. With these incentives aimed at globalization, more Chinese companies are settling down within Africa. China Wuyi Corporate Ltd., which came to Kenya in 2002 and has completed several very important infrastructure projects, such as the famous Thika Highway, unveiled its headquarters in Nairobi

21 Liu Haifang, "Mapping the New Migrants between China and Africa".

22 Liu Haifang, "Chinese Companies in Africa: Status quo and trend".

23 CADF Website <http://www.cadfund.com/NewsInfo.aspx?NId=1026> 
in 2014 to gain the confidence of the host community by showing its determination to stay in this market. ${ }^{24}$

The impression that China is coming to Africa as a resource hungry power has been attributed to the methodological oversimplification of China's presence in Africa and the underlying mindset or perception of China as a monolithic entity with one grand strategy of Africa. ${ }^{25}$ China's expansion in the area of resource need has frequently been reported as well as its interest in large state-owned national oil companies set up in Africa. Compared with Africa's traditional partners whose main activities are in mining extraction, China's presence and the associated impacts in Africa are rather limited. The truth is that China does have diversified interests in Africa, and the drivers, as well as the actual actors, also vary because while some come with the active support of the Chinese government, others come on their own. The exaggerated narrative on the one-dimensioned resource-driven Chinese agenda in Africa, ${ }^{26}$ so far, has overshadowed the multifacetedness of China's interest in Africa. Apparently, the agenda is increasingly widening as well as deepening as the latest session of Forum of China African Cooperation (FOCAC) held in South Africa and the second White Paper on China's African Policy launched in December 2015 shows. ${ }^{27}$

24 Xinhua News, "China Wuyi's Africa Story", 4 April $2016<$ http://mp.weixin.qq. coms? _biz $=$ MzA5MTEyNzU3OQ $==\& \operatorname{mid}=402103377 \& \mathrm{idx}=1 \& \mathrm{sn}=$ de4b60̄ db966e9b04e24a49a7c17f3ac8\&scene $=1 \& \operatorname{srcid}=0404 \mathrm{LqqKa}$ 6EHn6m2Y96g7UTA\#wechat_redirect>

25 Joshua Eisenman, Joshua Kurlantzick, "China's Africa Strategy", Current History, May 2006, pp. 219-224.

2. Such as a quite recent academic paper published by Meaza Zerihun Demissie claimedÿ"As one of the world's largest consumers, China has turned to SSA for natural resources, " and "China's foreign policy is characterized by noninterference in internal affairs, which creates a safe haven for politicians to misuse resource revenues. As long as African governments are corrupt, the real impact of China's involvement will not be known." Refer to Demissie, Meaza Zerihun, "The Natural Resource Curse in Sub-Saharan Africa: Transparency and International Initiatives" (2014). Dissertations. Paper 6,University of Southern Mississippi.

27 On the 6th session of FOCAC, refer to the website of FOCAC < http:// www.focac.org/eng; on the white paper, refer to http://news.xinhuanet.com/ 2015-12/05/c_1117363276.htm> 


\section{NEW CHINA-AFRICA COOPERATION - AWAY FROM THE NORTH-SOUTH TRADE MODEL}

A new round of reflection on China-Africa relations obviously was stimulated by the hit that Africa has taken from the low price of world staple commodity market. China was partly blamed for this slump as its decline in demand affected Africa. ${ }^{28}$ It seems that China-Africa trade does not encourage industrialization, and Africa stays indefinitely as raw materials exporters to China in exchange for manufactured goods, not so much different from the existing North-South trade model. ${ }^{29}$ This is a simplified attempt to understand the China-Africa cooperation based on limited information. Instead of providing a generalized reply to this type of judgment, the article would like to use a case-country approach to see what kind of implications China's cooperation has brought. Angola, as the biggest trade partner for China from the continent and even the biggest supplier of oil from the whole world for a period of time could be one of the best cases reflecting the characteristic of African external-dependent economy based on primary commodity, normally explained under resource curse principle.

The relationship between China and Angola has been called a perfect marriage which has been beneficial to both sides apparently; ${ }^{30}$ yet this relationship has also been interpreted as the most "unequal equals", quoting Nyerere's famous words to define the asymmetric bilateral relation between China and Ghana. ${ }^{31}$ A report published in 2009 reports a departure from other vulnerable African countries under China's offensive. ${ }^{32}$ It shows how Angola has maximized benefits from cooperation with Asian national oil companies, especially in comparison with the failed Nigerian government. This collaboration

28 The Age (Australia), "China's Slowdown Blights African Economies".

29 Demissie, Meaza Zerihun, "The Natural Resource Curse in Sub-Saharan Africa: Transparency and International Initiatives".

30 Indira Campos and Alex Vines, Angola \& China: A Pragmatic Partnership, Working Paper Presented at a CSIS Conference, "Prospects for Improving U.S.-ChinaAfrica Cooperation," 5 December 2007.

31 Horace Campbell \& Sreeram Chaulia, "Unequal Equals: Angola \&China", World Affairs, Spring 2009, vol. 13, No.1, pp. 44-83.

32 Mark T. Jones, "China and Africa - Colonialism Without Responsibility",7 Mar 2011 <http://www.articlesbase.com/politics-articles/china-and-africacolonialism-without-responsibility-4359573.html> 
marks a milestone in explicitly representing an Angolan agenda in the bilateral relationship. ${ }^{33}$

China-Angola contact dates back to the 1960s when the Angolans gained their independence from Portugal. China's anti-imperialist policy brought its material assistance to all three major movements. In 1975, facing the tri-liberation movements' segmentation, the Chinese government initially proposed a coalition government, ${ }^{34}$ then had to sacrifice its consistent standpoint of South-South cooperation for the greater geo-political need: to counter the hegemony of the Union of Soviet Socialist Republics (USSR), which stood by MPLA (Movimento Popular para a Libertaçao de Angola). ${ }^{35}$ The impact of this period of time shadowed the pre-history of China and the MPLA government, an official tie only established in 1983. Some scholars think this was also part of the reasons why the Chinese governments have eagerly given the great number of concessional loans to Angola in its post-conflict reconstruction as kind of compensation. ${ }^{36}$

As the war finally approached its end, Angolans determined not to "grow seeds of failure any more as in 1992."37 To have an election based on their own agenda was unanimously agreed among all parties evolving from liberation movements since the beginning of the 1990s when Dos Santos-led MPLA government announced the all-around reconciliation policy and reformed the Soviet-style one-party government into multi-party election system. To finish the post-conflict reconstruction, therefore, is the need to urgently re-establish people's everyday life as well as continue the process of national reconciliation without excluding failed parties and the common people as before.

In other words, the reconstruction task facing the MPLA government physically was to disarm the National Union for the Total Independence of Angola (UNITA) rebels, remove all the ten million landmines,

33 Alex Vines, Lillian Wong, Markus Weimer and Indira Campos, Thirst for African oil: Asian national oil companies in Nigeria and Angola. London: Chatham House, August 2009.

34 Samir Amin, L 'Eveil du Sud, Paris: Temps des Cerises, 2008, p.148.

35 Horace Campbell and Sreeram Chaulia, "Unequal Equals: Angola and China".

36 Lucy Corkin, "Uneasy allies: China's evolving relations with Angola", Journal of Contemporary African Studies, Vol. 29, No. 2, April 2011, pp. 169-180.

37 Paul Jorge (a representative of MPLA), "The Role of Political Parties in Ensuring Free and Fair Elections in Angola", speech given in the conference "The Challenges for Free and Fair Elections in Angola". 
repatriate the four million displaced people to their hometowns (most came to big cities like the capital city, Luanda). All these turned out to be huge challenges for the capacities of municipal facilities, securities, and so on. Politically, it was to soften people's tough hearts cultivated during the 40 years of war, and reunite all nationals with a clear agenda towards a better daily life. ${ }^{38}$

Only six years after the end of the war, after visible changes have taken place both in the capital city Luanda and Humbo Bie, which used to be the ruling centres of UNITA, was a new National Election held in September of 2008.The logistic conditions, as well as basic infrastructure, were re-constructed largely under the hands of the Chinese. Given that the Angolan voters had suffered too much from the war, many of them voted with their stomach, ${ }^{39}$ which explained why the apparently well-delivering MPLA won the majority in Humbo, and only some traditional supporters are still on the side of UNITA.

As other observers favourably commented unanimously, the EU observer delegation wrote in their report, "Fully reflecting the six years fruit of reconciliation and peace building, it is the symbol of a united Angola". ${ }^{40}$ If this election is a milestone marking MPLA's successful transformation from a revolution movement into a modern political party with increasing expertise in governance and management, the six years of hard work of reconstruction had prepared for this turnaround. This showcases significant Chinese contribution to timely cooperation with Angola.

Yet, Chinese presence in Angola surely does not only lie in the construction sector. Independent Chinese traders and entrepreneurs came to Angola during the violent civil war in the late 1990s, earlier than both Chinese oil companies and a large number of construction

38 This national priority revealed itself through the theme of Angolan Pavilion set up in 2010 for Shanghai EXPO, "Angola ensures a better life", indicating postconflict reconstruction as immediate and prominent goal. However, the overall theme of the EXPO was "Better city, better life", emphasizing challenges brought by urbanization to the world generally.

39 David Birmingham, "The Role of Political Parties in Ensuring Free and Fair Elections in Angola", speech given in the conference "The Challenges for Free and Fair Elections in Angola", sponsored by British-Angola Forum, Chatham House, London, 4-5 July 2005.

40 The European Union Election Observation Mission, Angola: Final Report on Parliamentary Elections, 5 September 2008 < http://www.eueom-ao.org/en/ PDF/FR_EUEOM_ANGOLA > accessed on 28 March 2011. 
companies visible since $2002 .{ }^{41}$ Many of these early comers are well established financially and integrated within the hosting society of Angola already.

\subsection{African Dynamics in Perspective: The Ebb and Flow of the Angola Model}

Without taking these individual Chinese nationals into consideration, the essence of the bilateral cooperation at the moment is easily interpreted just like a relation based on capital in exchange for resources (oil in particular). China is seen as an unaltered partner given the huge amount of money flow between the two countries. The tell-all-term Angola model is fashionable. On the one hand, "the Angola model", a terminology created by the World Bank to acknowledge the success of the resource-for-infrastructure package arrangement between China and Angola is still often discussed by both policy makers and scholars. ${ }^{42}$ On the other hand, between the two countries, it is not used any more even though several new big loans from China have been announced since the financial crisis. Moreover, this way of cooperation has been copied many times and has become the most attractive way for other African countries to harness China's rapid presence for their own longterm benefit. Even the New Partnership for Africa's Development (NEPAD), the technical vehicle of AU, has also been trying the same way to start some regional cooperation with China in future. ${ }^{43}$ The question is, what is the Angola model, and why this ebb and flow in Angola?

Having embarked on some reform programmes twice under the request of the International Monetary Fund (IMF) in 1995 and 2000, Angola found it desperate to get financial support from the IMF. ${ }^{44}$ This poor relationship with IMF and other international donors did not

41 Interview to Mr. Xu Ning, the Chairperson of China-Angola Business Council, 5March 2009, Luanda, also refer to Liu Haifang, "Chinese Companies in Africa: Status quo and trend".

42 Bryan Land, "Getting the most out of extractives in Africa: Dealing With Market and Governance Failure", speech made on the international workshop "Investment and Governance of Africa's Resources for Economic Diversification and Development" held by Qatar Foundation, 18-19 December 2014, Doha.

43 Interview at the NEPAD Headquarters, Johannesburg, 16 February, 2011.

44 Tony Hodges, Angola: from Afro-Stalinism to Petro-diamond Capitalism, Oxford: James Currey, 2001, pp. 102-117. 
change, and the highly expected donors' conference did not materialize. When the 41 years of war finally came to an end, the priority was to kick off its national reconstruction in 2002. Therefore, from Angola's perspective, Chinese financing offered better conditions, lower interest rates, and longer re-payment time than the non-Chinese credit lines that Angola secured in 2004, and this facility was even more appealing than commercial loans. ${ }^{45}$ More significantly, through the 2004 credit line arrangement, the Chinese provided urgently needed funding for strategic post-conflict infrastructure projects that Western donors refused to fund.

"Integral to this renewed cooperation is China's need to access energy resources," 46 President Dos Santos remarked, adding, "China needs natural resources, and Angola wants development". ${ }^{47}$ He said this on the occasion of the Chinese Premier Wen's visit to Angola in June 2006. China started importing oil from Angola since the 1990s, just like other Asian countries trying to diversify its oil import from the Middle East; yet unlike its Asian partners' diversification of its refining capacity, China's refinery was constructed according to China's own sweet oil products and Angola's high quality oil fits quite well. ${ }^{48}$

The initial courtship was mutual, if not to exaggerate a positive Angolan experience. Among many attempts by other non-Western countries to seek cooperation since the late 1990s, President Dos Santos visited China in 1998 seeking for an upscale in the bilateral relationship between both countries, leading to the ratification of many pragmatic agreements. His journey in China might also be seen as a study tour especially in Shenzhen, where he probably saw the fastest development by then in the world. ${ }^{49}$ It is hard to measure how much this important tour contributed to Dos Santos's vision for Angola's future development and how he might have been inspired from what

45 Indira Campos and Alex Vines, Angola \& China: A Pragmatic Partnership.

46 Indira Campos and Alex Vines, Angola \& China: A Pragmatic Partnership.

47 "Angolan leader addresses OPEC summit in Saudi Arabia," Angola Press News Agency, 19November 2007, quoted from Indira Campos and Alex Vines, Angola \& China: A Pragmatic Partnership.

48 Alex Vines, et al., Thirst for African Oil: Asian National Oil Companies in Nigeria and Angola, pp. 34-35.

49 This is waiting to be revealed only when more official documents could be released. Refer to Pan African News Agency, "Dos Santos Returns from China", 18 October 1998 <http://allafrica.com/stories/199810180025.html> accessed March 28th, 2011. 
he saw in China. The significance, however, could be highlighted, given the similarities between the two countries, as Dos Santos elaborated in his letter to $\mathrm{Hu}$ Jintao: all the achievements that China has made have helped Angola and presented it a good model for its own development. ${ }^{50}$

Furthermore, evidence of Angola's dynamism might be seen in the number of visas the Chinese Embassy issued to Angolans, coupling with the increasing number of Chinese expatriates in Angola at the same time (such as in 2008, Angolans got 10,400 visas from China, and the mainland Chinese, 50,000 Angolan visas). Notably, most Angolans in China are active public or private business entrepreneurs, unlike the majority of the Chinese that are migrant construction workers. Nonetheless, the absolute quantity of Chinese traders and entrepreneurs in Angola are several thousand already, according to the Chinese embassy. ${ }^{51}$

The Chinese loans backed by oil, brought massive changes to Angola's appearance, so much so that the terminology Angola model described the success of this cooperation. Returning to the origin of the Angola model, there have been various interpretations. World Bank experts tend to deny its novelty pointing to a long tradition in the history of extracting sector. ${ }^{52}$ Brautigam refers to it as a barter-style trade arrangement, dating back to the period of construction of TanZam Railway when China exchanged its products with Africa directly. ${ }^{53}$ Namibian scholar Zongwe, however, focused on its role, as a new

50 "A congratulatory message to Chinese President Hu from Angolan President", Boletim Informativo, Edition No. 01, August 2008, p. 2.

51 Refer to "China, Angola Relations Excellent - Ambassador", Angop, 26 March 2009.

52 Vivien Foster, et al., Building Bridges: China's Growing Role as Infrastructure Financier for Sub-Saharan Africa, Washington DC: The World Bank, 2009.

53 Deborah thinks there is a long tradition that China exchanges goods directly with Africa, and Japan initiated resource-backed loan to India, and then copied this mode in late 1970s to fund China. Currently, China is copying this experience in its engagement with Africa, refer to Deborah Brautigam, The Dragon's Gift: The Real Story of China in Africa, Oxford University Press, 2009. Other scholars think it as a "barter trade", refer to Hannah Edinger and Johanna Jansson, "China's Angola Model Comes to the DRC", China Monitor (S. Afr.), October 2008, pp. 4-6. 
creation in 21 century, in fostering long-term and sustainable investment, compared with the one-shot trade arrangement. ${ }^{54}$

There might not be an end to the debate of origin, especially on who learnt from whom. ${ }^{55}$ Indeed, the oil-backed loans for infrastructure is an approach that Angola has been using since the 1980s. In a piece of Chinese literature on Angola, records show how Angola had Brazil to build the Kapanda Dam for it with oil as payment for all that Brazil spent in 1984.Under the arrangement, the Brazilian national oil company, Petrobras, was to get 6000 barrels crude oil per day for 12 years. ${ }^{56}$ At the first glimpse, this should exactly be the prototype of the 2004 agreement between the Chinese MOFCOM and Angolan Ministry of Finance. However, the former one just targeted one project while the latter was a package of many projects with the specific decisionmaking process and the way the capital operated being greatly different. At least, this has been taken as an efficient tool for Angolan presidency to secure spending priorities, bypassing the inefficiencies of the traditional financial system. ${ }^{57}$

Since the reform of the mid-1990s, the Chinese government has encouraged the provision of concessional credit as a major application of development aid. ${ }^{58}$ For many specific potential risks, the Chinese EXIM bank, as the implementer of this policy, was very prudent and the procedure was very long and slow, particularly in Africa. ${ }^{59}$ For

54 Dunia P. Zongwe, "On the Road to Post Conflict Reconstruction by Contract: The Angola Model" < https://www.researchgate.net/publication/228286407_On_ the_Road_to_Post_Conflict_Reconstruction_by_Contract_The_Angola_Model $>$ accessed 20 April 2015.

55 Chinese EXIM Bank of course would like to take credit for originality, refer to the article published by the bank, "Angola Model', little plays skillful effects", Chinese Foreign Exchange, Iss. 9, 2009, p. 29. During the interview the author had with the Bank, the analysts expressed no opinion on all the interpretations above, but emphasized that the Japanese loan arrangement to China in late 1970s was very different from the Angola model.

56 Cao Zhuxun, "Brazil Accepted Oil As Payment to Build Dam for Angola (translated from American Journal of Engineer News Recorder, 1984, Vol. 213, No. 23)", People's Yangtze River, No. 4, 1985, p. 70.

57 Alex Vines, et al., Thirst for African Oil: Asian National Oil Companies in Nigeria and Angola, p.46.

58 Liu Haifang, "China's development cooperation with Africa: Historical and cultural perspectives." The Rise of China and India in Africa, eds. by Fantu Cheru \& C. Obi, Zed Book, 2010.

59 Interview to Dr. Zhao, Risk Analyst of China Exim Bank, 17 December 2010, Beijing. 
example, an oral agreement of a credit of US $\$ 50$ million for economic housing in VIANA II was made between the China and Angola in the second year after the official bilateral tie was conceived; yet the EXIM Bank and Angola Bank did not sign the final agreement till 1997. ${ }^{60}$ Resource-backed loan gives EXIM Bank enough sense of safety, and comparatively, the scale of loans has multiplied, and the procedures hastened since the new century. In the entire African continent, the credit line given to Angola was not the first using this type of arrangement, some studies show several loans previously given to other countries besides the small scale facilities (see Table 3 ).

Table 3. China's Investment in African Infrastructure ${ }^{61}$

\begin{tabular}{|c|c|c|c|c|}
\hline $\begin{array}{l}\text { Host } \\
\text { country }\end{array}$ & Year & Value (\$) & Project Title & $\begin{array}{l}\text { Resources } \\
\text { for } \\
\text { payment }\end{array}$ \\
\hline Congo & 2001 & $280 \mathrm{~m}$ & Congo River Dam & Oil \\
\hline Zimbabwe & 2006 & - & $\begin{array}{l}\text { Construction of coal } \\
\text { mines \& thermal } \\
\text { power stations }\end{array}$ & Chrome \\
\hline DRC & 2008 & $\begin{array}{l}9 \text { bn reduced } \\
\text { into } 6 \text { bn }\end{array}$ & $\begin{array}{l}\text { Key road, rail and } \\
\text { other }\end{array}$ & $\begin{array}{l}\text { Copper \& } \\
\text { cobalt }\end{array}$ \\
\hline Ghana & 2007 & $562 \mathrm{~m}$ & Bui Dam & Cocoa \\
\hline Sudan & 2001 & $128 \mathrm{~m}$ & $\begin{array}{l}\text { Construction of power } \\
\text { plant }\end{array}$ & Oil \\
\hline Guinea & 2006 & $1 \mathrm{bn}$ & Souapiti Dam & Bauxite \\
\hline Nigeria & 2005 & $298 \mathrm{~m}$ & $\begin{array}{l}\text { Construction of } \\
\text { turbine power plant }\end{array}$ & Oil \\
\hline Ghana & 2010 & $510 \mathrm{~m}$ & $\begin{array}{l}\text { E-governmental } \\
\text { system \& expanding } \\
\text { water system }\end{array}$ & Cocoa \\
\hline Gabon & 2006 & $3 \mathrm{bn}$ & $\begin{array}{l}\text { Belinga iron ore } \\
\text { project, inc. key } \\
\text { infrastructure }\end{array}$ & Iron ore \\
\hline
\end{tabular}

60 "Angola-China Relations", Boletim Informativo, Edition No. 01, August 2008, p. 17.

61 Sources of the table: Martyn Davies, "How China Influences Africa's Development", presentation for OECD Global Development Outlook 2010 <http://www.oecd.org/dataoecd/50/54/45182621.pdf> accessed 5 April 2011; Ghana Embassy to USA, "Chinese Investors Provide US\$570m for 3 Projects" < http://www.ghanaembassy.org/index.php? mact=News,cntnt01, detail,0\&cntnt 01 articleid $=342 \&$ cn tnt01origid $=15 \&$ cntnt01returnid $=99>$ accessed April 6, 2011. "China Gives Ghana over \$3bn Loan”, September 20, 2010 <http://www.ghanaweb.com/GhanaHomePage/NewsArchive/artikel. php?ID=190684> accessed 5 April 2011. 
As indicated in the table, some countries had been using the same resource-backed loan for infrastructural development before 2004, the year China signed the agreement with Angola. "The Angola model" might have been the term selected by World Bank because of its unprecedented scale. Examining the years 2007 and 2008, it is obvious that those projects under the first US $\$ 2$ billion Chinese credit line through which almost all the projects were implemented, whereas the total sum the World Bank gave to Angola at the same time was just US $\$ 500$ million. ${ }^{62}$

Instead of debating on who first invented the model, the more meaningful question probably is, under what circumstances would it operate efficiently, smoothly and be mutually beneficial? It is rational to assume that the Chinese would have all loans backed by resources for the sake of security? The second credit line is given with an even lower rate than the first was a showcase of both confidence and preference on the Chinese part for this kind of cooperation. Yet for Angola, it seems the circumstance that is suitable for the Angola model has completely changed after 2007: the new loans have been signed without the insurance of oil as payment.

Since 2008 Angola's oil revenue has been greatly impacted by the world financial crisis and high-rank politicians, including Dos Santos himself, who has come back and forth to Beijing to request more financial support. Currently, several loans have been given through Chinese Development Bank, ICBC, and Exim Bank as well, and none of these took the same model. ${ }^{63}$ In a piece of Wiki leaked news in 2010, the Angolan President came to China to seek for commercial loan, instead of one backed by oil, and he expressed to the Chinese Ambassador that the "Angola model humiliated Angolans" because Angola has realized that it was neck deep in debt and would try to get itself out of this debt trap as the deal was collaterization with oil money. ${ }^{64}$

62 World Bank, "Angola Country Brief" < http://go.worldbank.org/6LIK1A3SS0> accessed 5 April 2011.

63 Indira Campos and Alex Vines, Angola and China: A Pragmatic Partnership; Alex Vines, et al., Thirst for African oil: Asian National Oil Companies in Nigeria and Angola, pp. 53-54.

64 Ghana Webnews, "Foreign Loan-Trap: Ghana Government Is Walking into an Angolan Syndrome- NPP UK and Ireland Warns", 11 January $2011<$ http:// www.ghanaweb.com/GhanaHomePage/NewsArchive/Ghana-government-iswalking-into-an-Angolan-Syndrome-201027> retrieved on 5 April 2016. 
If this news was solid, the real reason that the Angola model was not duplicated any more in Angola might be really from Angola's new concern after seeing the first round post-conflict reconstruction. People need more jobs, and the oil revenue is expected to bring in more change than the reconstruction of infrastructure. This should be seen as a sign of Africa's dynamics and the key forces that shape, reshape or even reverse the direction of the cooperation with China, and how China's agenda is perceived.

\section{HARNESSING CHINA'S PRESENCE FOR LONG-TERM BENEFIT}

After the civil war, the booming oil price accelerated Angolan economic growth, which also lifted the self-confidence of the Angolan government to persist on its own approach to gradual reform domestically and an independent foreign policy not dominated by external forces. As early as 2002, the year the war finally came to an end, many international aid organizations crowded in to provide humanitarian assistance. This year saw an official figure as high as US\$421 million's foreign aid to Angola. Yet, the Angolan government sturdily refused to allow Genetically Modified Food (GMF) into the country, so that many aid programmes of these international organizations came to a standstill. ${ }^{65}$ Likewise, the tough attitude of the Angolan government reveals itself frequently during its contact with IMF to secure funds for reconstruction, which eventually gave up halfway and made it turn to China for support.

Probably similar to the experience of President Julius Nyerere, who ran around the world in vain looking for the money to fund the TanZam Railway before he finally came to China, hesitating till the last minute whether or not to speak frankly to the newly established PRC government that was also not in a prosperous condition. Like the then Angolan government, Nyerere unexpectedly got the firm promise from China immediately. Yet this timely help required the Angolan officials to be quite open about the sum of money involved in their cooperation with China and also very candid about not wanting to depend on any single partner. ${ }^{66}$ As "a masterful negotiator", the president dared to

65 The Financial Times, "World Desk Reference: Angola" < http://dev. prenhall.com/divisions/hss/worldreference/AO/aid.html > accessed April 5, 2011.

66 Alex Vines, et al., Thirst for African oil: Asian national oil companies in Nigeria and Angola, p. 56. 
state, "you are not our only friend" to his Chinese counterpart. ${ }^{67}$

Practically, after the first national election in which the MPLA government saw the overwhelming votes as a test of the stability of the ruling party, the Angola-China relations should have concluded its journey perfectly in Angola's agenda of post-war construction. President Dos Santos made a clear statement at a diplomats working meeting. According to him, "Globalization naturally makes us see the need to diversify internationally [and] replace the petrified concept of zones of influence that used to characterize the world." ${ }^{68}$ China had become just one of the partners in the Angolan array of strategic international development partners, together with France, Portugal, and Brazil. These then became the most important four partners' bilateral affairs jointly managed by the Reconstruction Office (Gabinete de Reconstrução Nacional GRN), which used to be in charge of all the cooperation with China.

If there was no emergency as was the case during the post-conflict reconstruction, the Angolan government probably would not have used the Angolan model again to access Chinese capital. In other words, it would not have used that approach during the financial crisis even though large-scale infrastructural development was a top priority. In MPLA's programme for 2009 to 2012 and the government Vision 2025, to diversify its economy (especially agriculture) and reduce the heavy reliance on oil revenues have become the new priorities. This means that the ability of Chinese investments to adapt to this new agenda is crucial for its long-term position in the market, and consequently followed by challenges of financial, managerial as well as technological capacities and adaptabilities.

Late 2010 saw a final strategic partnership agreement signed during Vice -President Xi Jinping's visit to Angola. Notably, the benefits Angola gained from the bilateral cooperation with China clarified its vision, as Angola said about their entry Expo in Shanghai, "Our goal is to attend Expo with dignity and responsible image, and beginning from this point we want to achieve a position in the world market".

67 "The Chinese in Africa: Trying to pull together", Apr 20, $2011<$ http://www. economist.com/node/18586448> accessed April 28, 2011.

68 José Eduardo dos Santos, "Presentation of New Year Greetings by Diplomatic Corps", Luanda, 10 January 2008ÿquoted from Alex Vines, et al., Thirst for African oil: Asian national oil companies in Nigeria and Angola, p. 56. 


\section{CONCLUSION}

This article differs from the overemphasized perspective, which has fuelled the widespread stereotype of China as a hungry dinosaur and Africa as incompetent and vulnerable. Angola's story is generally a gain: with the Angola model used temporarily to harness the presence of the oil-thirsty monster. The perspective of Angolan government is that China's presence presents a completely different opportunity, probably the most immediate and easy to access that an African country could have and take advantage of. Eventually, its long-term benefits can be achieved through bargaining and persisting in its visions, both domestic and external.

In the view of common Angolans, what could be more convincing than the rapidly re-habilitated Benguela Railway, which could directly bring their big or small business from the Atlantic coast to the inner land of Central Africa and even the Eastern African Arabians? ${ }^{69}$ Only through similar cooperation, could sustainable and mutual benefit result particularly for the resource countries the mining sector might attract. Observably, this stands for only one of many interests of the diverse players from China.

There is an internal structural dilemma within the China-Africa relations, inherent in China's immediate interests unavoidably overlapping with those host African countries'. One such interest is excess labour. ${ }^{70}$ For instance, in Angola's case, in the first phase of contracts of those projects under the umbrella of the first US $\$ 2$ billion loan package, the Chinese companies were given all the projects. However, under the requests of Angola people, in the second phase, 30 per cent was left to Angolan construction firms as local content. This 70 per cent was still criticized vocally by Angolan economists (let alone the media, NGOs, etc.), because "the construction sector is one in which Angolans hope they can find work". ${ }^{71}$ The increasing local

69 The recently launched movie shot by BBC Angola entitled "the Chinese Are Coming", actually vividly recorded how the village economy is rejuvenated after the Bengula Railway reopened and the western coast and Eastern coast of Africa finally reconnected through the landline.

70 The analysis on the in-born structural dilemma of China-African cooperation, refer to Liu Haifang, "Post-crisis development of Sino-African Cooperation: practices and perceptions", China International Strategy Review 2011, World Affairs publishing house.

71 EIU, Angola Country Report, September 2006, p. 16. 
pressure, it is believed, partly contributed to the end of the Angola model. Predictably, further cooperation with Chinese firms coming to Angola will strictly limit the number of Chinese workers. All these challenge the Chinese firms to upgrade their business and transfer more technologies to Angolan nationals if they are to stay long in this market. ${ }^{72}$

It does not necessarily mean that both sides must effortlessly harmonize their readjustment for cooperation, given the diverging perceptions of each party. Since 2004, the Chinese workers involved with Chinese Construction Firms (CCFs) were very visible in Angola Market, and the prominent presence of the Chinese has been widely criticized. The Chinese ambassador's interpretation focused on the poor input of locals while the Angolan owners of the projects request speed. ${ }^{73}$ Interestingly, a high-rank Angolan official regarded these jobs as temporary and not meant for local workers, who deserve permanent positions after these temporary Chinese migrant workers help to complete infrastructure and new factories and service sectors are built up. ${ }^{74}$ According to the minister, what Angola has benefitted from these Chinese CCFs, most importantly, is the low-cost techniques. African construction market may not be able to solve China's rural and agricultural issues, but has served as one temporary way to increase income, sometimes two to threefold of those temporary migrant workers compared to what they could earn domestically.

The popular discourse has portrayed that the China-driven commodities super cycle over the past decade or so may have reinforced the resource dependence of African states. ${ }^{75}$ Angola's deal with China has impacted on its own development, especially by diversifying its economic sectors as well as its partners in the world. There is notably, a lot to learn from Angola's case to master the most unequal equal relationship and to gain from the current south-south cooperation with all emerging powers, especially China.

72 Interview to Golden Nest Group, Luanda, 28 January 2011.

73 Cecile de Comarmond, "China lends Angola \$15bn, but few jobs are created" <http://mg.co.za/article/2011-03-06-china-lends-angola-15bn-but-few-jobsare-created $>$

74 Angolan Finance Minister, "China: A Precious Partner, Though Still Disputing and Secretive", a Speech given on the conference "Angola: Present situation and tomorrow outlook", 11 April 2008.

75 Martyn Davies, "What China's Economic Shift Means for Africa" < http:// www.lawyersforafricablog.com/files/2015/03/Screen-Shot-2015-03-31-at11.15.57-PM.png> 
As China's current strategy towards Africa matures, so does Africa's strategy towards China. Beijing has never been just an actor in Africa's resources sector, and recently it has significantly broadened the scope of its commercial foray into the continent, indicated in the recent development of manufacturing strategy launched in May 2015. 